\title{
University-industry collaboration in the European regional context: the cases of Galicia and Apulia region
}

\section{Manuel González-López ${ }^{1}$, Ivano Dileo², Francesco Losurdo³}

\begin{abstract}
Universities are one of the key actors within national and regional innovation systems. The nature of university-industry collaboration has changed during the last decades and it varies across countries and regions. Different factors determine the interaction among both organizations, from those related to the industrial structure of the territory to others related to institutional and legal frameworks. In this paper we aim at adding to the understanding of this process based on the comparison between two European regions (nuts-2), Apulia in Italy and Galicia in Spain. Our results show that a progressive transition from a separated to a more integrated approach has occurred at the relational framework affecting universities and industry in both regions. Public policies, particularly from the regional level, have been relevant for promoting university-industry collaboration in Galicia and Apulia.

Nevertheless, there still remain cultural and institutional barriers, both from the academy and business sphere, which impede a narrower and more fruitful interaction. Besides, the poor innovative culture of traditional industries which dominate in both regions, might affect university-industry interaction. However, an adjustment of the university offer in terms of research is also needed as we observe that collaboration is too much biased by the university scientific and departmental specialization and too little by local and regional industrial specialization.
\end{abstract}

Keywords: University, industry, collaboration, regions.

\section{Introduction}

The experience demonstrates that a mutual integration between university and industry can foster the development of the communities in which both are operating (Camagni, Maillat and Matteaccioli, 2004). Moreover,

\footnotetext{
1 Manuel González-López, PhD, Lecturer and Researcher of Economics, ICEDE Research Group, University of Santiago de Compostela, Department of Applied Economics, 15782 Santiago de Compostela, Spain, manuel.gonzalez.lopez@usc.es. 2 Ivano Dileo, PhD Lecturer in Economics, University of Bari, Department of Political Science, University of Bari, 70121 Bari, Italy, dileoivano@gmail.com.

3 Francesco Losurdo, Professor of Economics, University of Bari, Department of Political Science, University of Bari, 70121 Bari, Italy, francesco.losurdo@uniba.it.
} 
important changes have happened in the rationale of university-industry relationship during the last decades (Gibbons et al., 1994; Etzkowitz and Leydesdorff, 2000). In general terms a tendency towards a narrower interaction among universities and companies has been observed, a trend that has changed rules and behaviours at both organizations. Nevertheless, such process is far from being a universal and barrier-free trend as economic, cultural and institutional factors may hinder or foster it. In many countries and regions, science remains an open system, governed by rules and practice set by the scientists themselves. Conversely, industrial research is likely to be specific in orientation and firms are focused on creating private and valuable knowledge that can be used to set-up process and produce goods. Although both university and industry have mutual interest in knowledge and research abilities formation and in technology transfer as well, they sometimes operate separately and follow different ways. The nature of universityindustry collaboration varies also across countries and regions because of different factors, from those related to the industrial structure of the territory to others related to institutions and legal frameworks.

In this paper we look at two experiences of university-industry cooperation at the regional level. For this goal we have chosen Apulia in Italy and Galicia in Spain. They are both NUTS II European regions, characterized by a similar research infrastructure focused on public universities, with a leader one (Bari in Apulia and Santiago de Compostela in Galicia), as well as an industry largely formed by SMEs based on traditional manufacturing. We aim at adding to the understanding of how institutional and productive specificities shape the collaboration between university and industry. In particular, we will try to answer the following questions:

a) to what extent universities in Apulia and Galicia have moved towards a more integrated model of interaction with industry and,

b) how the institutional set-up and the productive specificities of each region shape the relationship between universities and industry?

The paper goes as follows. First, we briefly discuss the literature about university and industry collaboration as well as its role on regional development. In the second and third section we present the major features of university-industry collaboration in Galicia and Apulia region respectively. We focus on the institutional and legal framework affecting interactions among both organizations as well as on the particularities of regional innovation and industrial structure. In the last part of both cases we present some recent evidence about the different channels of interaction among universities and industries.

We end with a conclusion part where we try to extract the main lessons about the comparison of the Galicia and Apulia cases. 


\section{Literature review}

\section{University transition from "mode 1" to "mode 2" of knowledge production and the determinants of university-industry relationship}

The university-industry relationship has been largely discussed by the literature on industry and innovation during the last decades. Such relationship is considered of high relevance for local and regional development as knowledge has been increasingly pointed out as a key factor for economic progress (Boucher, Conway and Van Der Meer, 2003; Gunasekara, 2006; Uybarra, 2010). Several studies have pointed out the basic role of the knowledge infrastructure for creating structural interdependencies with the industry (Alavi and Leidner, 2001; Basant, 2002; Bathelt, Malmberg and Maskell, 2004). In this sense, there is a growing awareness of the importance that university can undertake, especially at regional level (Fini, Grimaldi, Santoni and Sobrero, 2011).

Agreeing with Carlsson (1997) and Carlsson, Jacobsson, Holmèn and Richne (2002), this can include the generation of applied scientific knowledge that can be used by local high-tech industry attracting knowledge based firms to relocate into regional system (Castells and Hall, 1994) and create additional employment opportunities within the local labour market (Acs and Audretsch, 2003).

The impact of university-industry interactions on regional development became even more important since higher education institutions moved from a traditional role, focused on basic research and training, to a new role more involved in innovation and productive tasks. Such change has been well described by Etzkowitz and Leydesdorff (2000), among others, referring to the new role of universities as one inserted in a "Triple Helix Mode" of innovation. In such a model, universities will be one blade, together with firms and governments, for the development and use of new knowledge in the economy and so for promoting competiveness and economic progress. Under this view new functions of universities are emphasised such as technology transfer, spin-off creation, patent licensing, etc.. More recent contributions have somehow renewed the "triple helix" idea pointing to the existence of a "quadruple" and even "quintuple" helix innovation model (Carayannis and Campbell, 2011). Thus the quadruple helix mode will incorporate media, culture and the civil society perspective into the process of knowledge creation and innovation whilst the quintuple mode will do the same with the natural environments of society.

According to Gibbons et al. (1994) the growth and spread of higher education after the Second World War was hand to hand with a change in 
the view of university roles in society. It would begin with a world where universities were the ones providing basic knowledge (from basic science) to large-scale industry, relying upon a linear model of innovation where both actors were clearly separated and showed completely different rationality. a second phase, beginning in the late 60s, will emphasise the role of applied science and knowledge produced by universities and so its dissemination and applications. The importance of linking higher education institutions and the productive systems, despite belonging to two different spheres, increased. a third stage will emphasize even more the role of technological innovation for competitiveness and so the removing of barriers and bottlenecks between the scientific enterprise and industrial innovations. Finally, since the 90s, industrial policy, science and technology policy and regional policy converged towards a common innovation policy. In this context, universities entered the scenario as major players for the creation of a knowledge-based economy. Higher education institutions created and participated in science and research parks, cooperative research centres and consortia with industry, business incubators, etc.

The new and fashionable concept is the "entrepreneurial university" (EDU, 2007). Gibbons et al. (1994) describes such transition of universities from a "Mode 1" of knowledge production, which is governed by the academic community and its rules, to a "Mode 2" of knowledge production resting on a bidirectional connection between academy and society in which the boundaries between the two worlds are blurring.

Transition from "Mode 1" to "Mode 2" is narrowly linked to the participation of universities as actors in the "triple-helix" model, particularly within regional innovation systems. The innovation system approach views innovation as a collective process where regional innovation emerges from localized and institutional supported networks.

Such a "regionalization" of the phenomenon of innovation explains also the trend towards regionalization of S\&T policy and governance. Universities, together with firms and regional governments would hence be key actors with the regional networks of creating, disseminating and using knowledge for economic purposes and so they will shape the evolution of the regional economies.

Regional innovation systems can be both viewed from a top-down and a bottom-up perspective (Howells, 1999). From a bottom-up perspective, the concept of regional innovation system links to the economic geography literature where proximity and networking are determinant factors for explaining local and regional development. In this sense, universities might take part (or not) of industrial clusters as part of the networks participating in knowledge production and diffusion and for the creation of spill-over effects. 
Such localized clusters, not necessarily uni-sectorial, would follow a trajectory and will be also narrowly shaped by social, cultural and institutional factors.

In this case, the term "region" rests mainly on a geographical dimension as sometimes such clusters can be localized in border spaces of two different countries. $^{4}$

On the other hand, from a top-down perspective regional innovation systems will be conceived similarly than national innovation systems, so their delimitation will rest on the regional governance structure (formal institutional specificities), as well as on productive issues referring to industrial specialization and core/periphery differences.

According to this view, we can argue that the role of universities in innovation systems will be firstly determined by existing regional regulations affecting higher education, secondly, by the industrial specialization profile of the region. The definition of "region" from this perspective refers largely to a historical or administrative space, i.e. formal institutions like governments and legal frameworks are relevant. In this paper, considering the nature of the two regions compared, we will take this last perspective (top-down).

The changing role of universities in regional development that has been observed in many countries is shaped from our viewpoint by two different factors. First of all, the specificities of the institutional set-up where universities are embedded are relevant, as transition from mode- 1 to mode- 2 might be burdened by institutional resistance. In many cases a change in the institutional set-up and legal framework affecting universities will be needed in order to adopt new roles. At the same time, legal frameworks and their modifications are embedded in national and regional institutional realities that differ from one territory, even from one university, to another. Therefore, in order to understand the impact of university-industry relationships on regional development we must analyze such institutional and legal framework in depth.

Second, the specificities of the regional industrial structure, as not all sectors present a similar propensity to use university knowledge, also matter (Gonzalez, 2000).

Industries and sectors differ in their innovative character or in the type of knowledge used. Isaksen and Karlsen (2010) point out that the role of universities for regional development is determined by the dominant mode of innovation of the regional industry, distinguishing between DUI (doing, using and interacting) and STI (science, technology and innovation) ${ }^{5}$. When

4 The GREMI school refers to a similar concept than the one used here labelled as "Millieux Innovateurs", Aydalot (1986). 5 The STI-mode operates mainly on the basis of the codified knowledge while the DUI-mode operates mainly on the basis of experience based learning by doing, using and interaction (Lundvall, 2006). 
comparing the case of two Norwegian universities, Tromso and Agder, they conclude that the dominant mode of innovation in a regional industry makes a difference to the role universities can play in stimulating the development of the industry. For instance, cooperation is more easily found if STI dominates in the regional industry than if DUI dominates. Such results nevertheless contrast with the view raised by Lundvall (2006) when he points out that: in the current period where protection of codified knowledge has become a major concern of rims that are world leaders in advanced technology this might not be the case. The STI-mode resulting in disembodied codified knowledge may actually result in more restrictive access than the DUI-mode where the final product is a new system or product with embodied but unprotected knowledge (p. 22).

\section{Discussion}

\section{University-industry collaboration and the institutional framework in Galicia}

There are three universities in Galicia, the centenary University of Santiago de Compostela (USC) established in 1492 and the Universities of Vigo (UVIGO) and a Coruña (UDC), which were created in 1990 as a disaggregation of the University of Santiago. The USC is the largest of the three institutions both in terms of number of students and personnel as well as regarding the number of departments and research groups. In regard with the main research areas, there is a certain complementarity among the three universities although some overlapping is also found particularly in the field of social sciences. The USC shows a strong specialization on health sciences and also on classical disciplines from different fields (Law, Economics, Philosophy, Languages, Biology, Chemistry, etc). The UVIGO is the one with more focus on technology and industrial engineering whilst the UDC major distinctiveness refers to Architecture and Civil Engineering and Computer studies.

There are two key milestones referred to institutional changes that are relevant for the evolution of the relationship between university and industry in Galicia. The first one refers to the approval of two laws at the national level. The first one is the law for the University Reform approved in 1983, which regulated the collaboration between the academic staff and companies through contracts and collaborations agreements. Secondly, the Law for the promotion and general coordination of scientific and technical research, published in 1986. This law includes the objectives of promoting the knowledge and technology transfer from universities to the productive system and creates the conditions for the set-up of offices in charge of such 
function (TTOs) in most universities. As a result, and supported by the National Plan of R\&D, the number of TTOs at universities strongly increased in a short period of time reaching 40 1992. In Galicia, each of the three universities established their office in 1991. According to Rubiralta (2007), since year 2000 an evolution of the TTOs has been observed as they increasingly adopt a rather complex structure and more functions. This author considers this trend as a common one for many European universities in such a way that apart from the traditional function, some others can be identified such as patents management, technology-based companies promotion, entrepreneurship promotion, Spin-offs management and promotion, capital-risk functions, technological incubators set-up and participation in technological and scientific parks.

Table 1. Galician Universities (2012)

\begin{tabular}{|c|c|c|c|}
\hline & Students/Scientific Staff & $\begin{array}{l}\text { Departments/Research } \\
\text { Groups }\end{array}$ & $\begin{array}{l}\text { Main Research } \\
\text { Areas }\end{array}$ \\
\hline USC & $30.159 / 2.094$ & $75 / 355$ & $\begin{array}{l}\text { Health Sciences } \\
\text { Natural Sciences } \\
\text { Social Sciences } \\
\text { Humanities }\end{array}$ \\
\hline UVIGO & $22.103 / 1.472$ & $47 / 252$ & $\begin{array}{l}\text { Technology and Industrial } \\
\text { Engineering } \\
\text { Social Sciences } \\
\text { Natural Sciences }\end{array}$ \\
\hline UDC & $22.819 / 1.448$ & $43 / 126$ & $\begin{array}{l}\text { Social Sciences } \\
\text { ICT } \\
\text { Architecture and Civil } \\
\text { Engineering } \\
\text { Ship-building Engineering }\end{array}$ \\
\hline
\end{tabular}

Source: Own-elaboration.

The second key institutional milestone refers to the regional (Galician) level and particularly to the publication of the Law for the promotion of research and technological development in 1993 as well as the subsequent first Galician Plan for research and technological development in 1999. The delay in the launching of the plan reflects the difficulties to establish a coherent and integral strategy for R\&D in the region. In fact, as pointed by Conde-Pumpido (2007), the first measures to articulate the Galician innovation system and the relationship between universities and firms were only included at the second Plan (2002-2005). According to the previous author the regional policies implemented during the 90 s rested on the separation between the scientific and technological spheres, with the public R\&D system as dominant 
actor; whilst in the second RTD Plan (Conde-Pumpido, 2007) an evolution towards a rather technological and entrepreneurial model was observed ( $p$. 80). As a consequence the collaboration between universities and industry increased at their different forms.

The plan supported the TTOs of the universities as well as different structures to promote the commercialization of research results or the establishment of technological based companies. Many of the investments of the related infrastructure were financed by EU funds.

Apart from the legal development indicated above there are other landmarks that determined the relationship between universities and industries in Galicia. One of them refers to the establishment of the Galician University-Firms Foundation in 1982 that join together the main regional firms and the University of Santiago de Compostela (the only existing at that time) to promote the collaboration between universities and industry. Its activities were largely focused on supporting the incorporation of graduates in Galician companies as well as research and consultancy contracts between research groups and firms. Another important issue refers to several initiatives taken by the University of Santiago de Compostela at the end of the 90s and beginning of the 2000s.

One of them was the establishment of the first university spin-off incubator in Galicia, UNINOVA, in collaboration with the local authorities. The other was the setting up of UNIRISCO, a venture capital society aimed at providing financial support to universities spin-offs, which was created in collaboration with relevant Galician companies and financial institutions, and that later incorporated also the Universities of Vigo and a Coruña.

\section{Regional innovation and industrial specialization of Galicia}

Galicia shows a moderate-low innovative profile in the European context (EU, 2014).

During the 90 s and the first decade of the current century, R\&D expenditure on GDP continuously increased its share on GDP reaching $1 \%$ in 2008, when the crisis broke out. Since that year there has been a slight decreasing in this indicator and at the moment is lower than half of the EU-27 average. Differences with the EU are even larger when dealing with Business $R \& D$ expenditure, which is approximately half of total R\&D expenditure. Finally, patent activity is even lower than the previous indicators as the average patent application to EPO per million inhabitants was around 12 per year between 2006 and 2010, ten times lower than the EU average. The innovative performance is closely linked to productive specialization and, as 
we will see below with more detail, Galician economy shows a relatively low presence of high-tech sectors.

Table 2. Main innovation indicators of Galicia and EU-27

\begin{tabular}{lrr}
\hline & \multicolumn{1}{c}{ Galicia } & \multicolumn{1}{c}{ EU-27 } \\
\hline Population (2013) & 2.761 .989 & 501.403 .599 \\
GDPpc (PPS) (2011) & $21.800 €$ & $24.600 €$ \\
Unemployment Rate (2012) & 20,5 & 10,4 \\
R\&D Exp/GDP (2011) & 0,94 & 2,01 \\
Business R\&D Exp/GDP (2011) & 0,46 & 1,24 \\
Patent Applications to EPO per million inh (Aver. 2006- & 11,94 & 111,56 \\
2010) & 5,7 & 10 \\
\hline High-Tech Sectors (\% Total Employment) (2011)* & & \\
\hline
\end{tabular}

* High-Tech Manufacturing + High-Tech Knowledge intensive services Source: Eurostat..

The Galician economy could be included within the group of late industrialised and peripheral European regions as it remained dominated by primary sectors until the $70 \mathrm{~s}$ and manufacturing boomed only during the second half of the last century. Nowadays the peripheral character of European regions shows a rather different profile than the one it used to show. As pointed by Vence-Deza and González-López (2008), the peripheral character of European regions is now shown by a stronger presence of lowtech manufacturing industries and traditional or non-knowledge intensive services.

This is also the picture on the Galician industrial structure in comparison with the EU-27 and, to a less extent, with the Spanish one. Thus, the Galician manufacturing sector is dominated by food production, with a long tradition on seafood production, textiles and wearing apparel where successful companies like Inditex (Zara) became large MNEs, wood and derivates and non-metallic mineral products. Together with the previous branches, the manufacturing of vehicles and ships represent the core of the Galician manufacturing specialization. High-tech manufacturing like computer and electronic products, electrical equipment, machinery and equipment or chemical and pharmaceutical products are poorly present in the Galicia economy. Regarding services activities, the presence of knowledge intensive services is comparatively low in Galicia, particularly when dealing with knowledge intensive business services like R\&D activities, computer and related activities or telecommunication. According to Gonzalez-López (2009) in a study made for the Spanish case, such services are usually concentrated 
at capital and metropolitan regions from which they are "exported" to peripheral regions with less developed knowledge intensive business services.

Figure 1. Relative industrial specialization.

Galicia/EU-27 and Galicia/Spain (2010)

\section{Relative Specialization Galicia/EU-27 and Galicia/Spain}

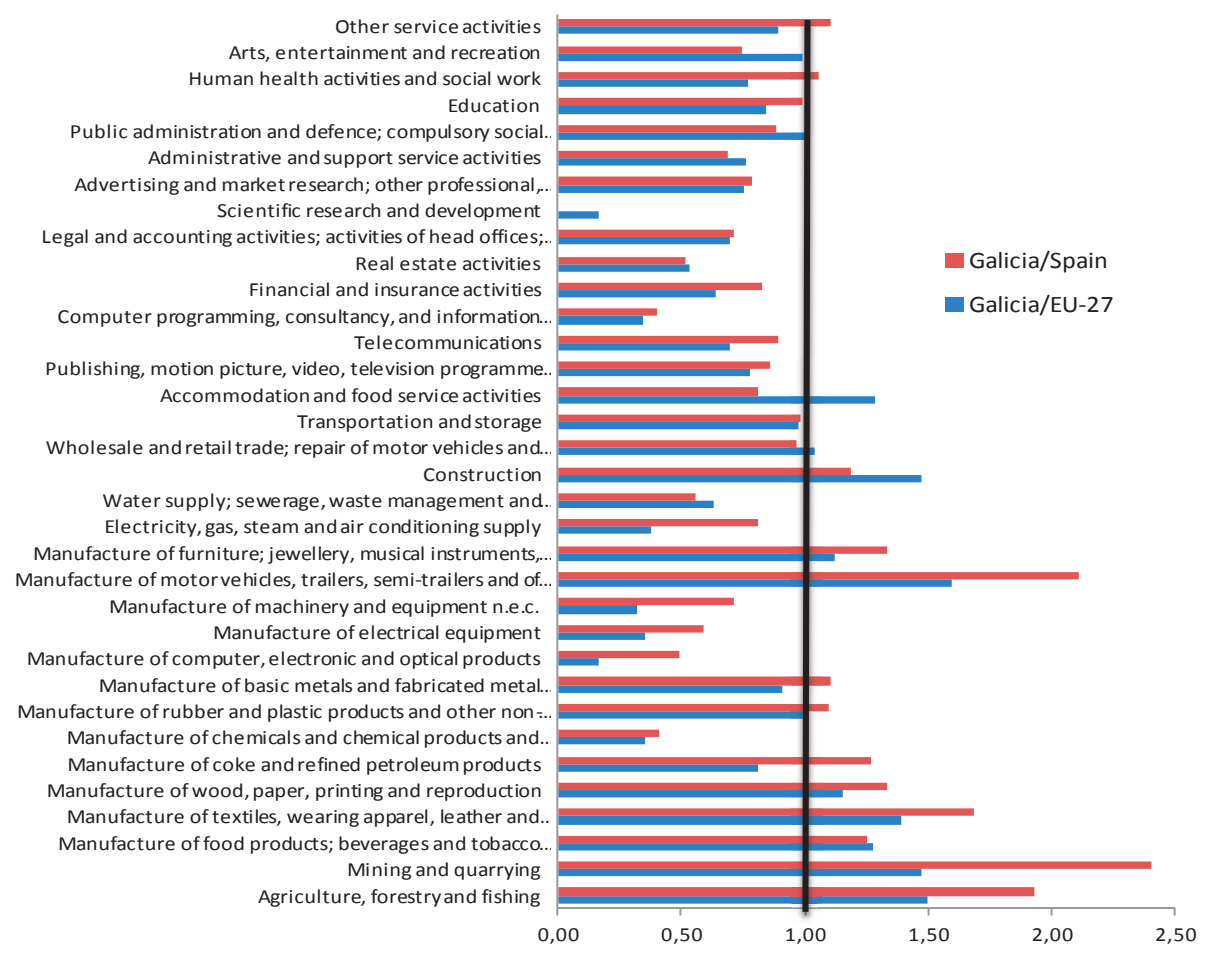

Source: Own-Elaboration based on IGE (Galician Statistical Institute) and Eurostat data.

\section{University-industry interaction in Galicia: recent evidence}

A few studies have analyzed the connection between businesses and universities in Galicia during the last decades (Vence-Deza, 1992; CondePumpido, 2007). In a study made for 1998 and 1999, González-López (2000) pointed to certain structural deficiencies of university-industry collaboration in Galicia due to the specialization on low-tech and traditional sectors as well as the lack of specific public support. These deficiencies were shown on the poor connections between them, based mainly on fragmented R\&D contracts and services. Another barrier found, as also pointed out by VenceDeza (1992), referred to the different interests and institutional behaviours of both partners. 
In the present research we have collected data from the three Galician universities about the different channels of interaction with industry (including public bodies). Some of this data is published and freely accessed from the universities web-sites while other was collected from the universities TTOs. At the same time we have interviewed the directors of the three universities TTOs in order to obtain qualitative insights from the characteristics, evolution and barriers of university-industry collaboration in their universities and in Galicia as a whole.

Table 3 sums up the evolution and the current state of three different channels of collaboration between university and industry in Galicia. These channels are R\&D contracts and services, patent applications as well as spinoff creation. We have analysed the period 2007-2013 in order to obtain some insights about the impact of the crisis bursting in 2008. It is important to note here two aspects. First, both patent activity and spin-off creation are quite recent phenomena (particularly the last one), for this reason previous studies like some of the ones mentioned above did not contemplate it. Second, interactions for training and educational purposes are not included here as it is a pending issue in the Galician innovation system. Such interactions refer only to short and not-paid interships at companies and public bodies (1-3 months) during bachelor and master degrees that in many cases are just a requisite to obtain a degree. We do not find, in contrast with other European countries, experiences of companies funding PhD programmes or similar initiatives. Referring to the pointed channels of interaction we have observed that during the last two decades R\&D contracts and services between universities and industries have grown both in terms of number and their economic amount. This growing tendency has only disappeared due to the impact of the economic crisis beginning at the end of 2008, as observed in the table. Only a tiny recovery is noted since 2012. When dealing with patent applications a growing tendency is also observed in the period analyzed, although the numbers are still quite poor when comparing with European universities. The impact of the crisis does not seem to be relevant, something that is quite understandable as the patent applications are usually the final stage of long-term research (so there is time-gap and the crisis could affect patent activity during coming years).

Finally, when dealing with spin-offs creation an increasing trend is also observed even during the period of crisis. In some cases this might be explained by the reduction of public funds for research that brought some researchers to become entrepreneurs. In any case spin-off creation is, as mentioned above, a relatively recent phenomenon that in the cases of UDC and UVIGO began in mid-00s, thanks to the support of a specific regional programme. The main knowledge fields and economic sectors of collaboration vary from 
one university to the other, according chiefly to their specialization profile. Most active knowledge fields in the USC refer to health, biotechnology, ICT and environmental S\&T. In the case of the USC, the interaction with the economy takes a rather cross-sectoral profile, not aimed specifically to one economic sector. Only in the case of health sciences we find a specific sector of interaction that is the (regional) public health system, since the presence of private health companies is quite modest. Other activities like the food industry as well as fishing and aquiculture sector used to be among the most collaborative ones; nevertheless their relevance as R\&D partners has recently decreased due to different reasons. The geographical space of reference is the Galician economy as a whole as there is not a strong local specialization in any industry. Regarding the UVIGO, the outstanding knowledge fields are industrial engineering, marine sciences and ICT. In relation to the economic sectors more prone to collaborate we find a closer relationship with the local environment, as the city of Vigo shows an important industrial tradition in the regional context. The major sectors are the automotive auxiliary industry, with strong presence in the city of Vigo, as well as the food industry (both seafood and agrarian related). Finally the ship-building industry, also relevant in the area of Vigo, is another major partner of the university. To end with, the UDC main knowledge field of collaboration are ICT (due to the presence of computer studies), civil engineering and natural resources and environment. This university is probably the one with the poorest connections with its industrial (local) environment and only the ship-building industry shows certain commitment with R\&D collaboration. Like the case of Santiago but in a sensible minor scale, the interaction with the productive system in this case is mainly cross-sectoral, linked to ICT and environmental technologies.

Table 3. Channels of interaction between Galician universities and industry

\begin{tabular}{|c|c|c|c|c|c|c|c|c|c|}
\hline & & \multicolumn{2}{|c|}{ 2007-2008 } & \multicolumn{2}{|c|}{$\begin{array}{l}\text { Average } \\
\text { 2009-2011 }\end{array}$} & \multicolumn{2}{|c|}{$\begin{array}{l}\text { Average } \\
\text { 2012-2013 }\end{array}$} & \multirow{2}{*}{$\begin{array}{l}\text { Main Knowl- } \\
\text { edge Fields of } \\
\text { Collaboration }\end{array}$} & \multirow{2}{*}{$\begin{array}{c}\text { Main Economic } \\
\text { Sectors of Col- } \\
\text { laboration }\end{array}$} \\
\hline & & Number & $\begin{array}{l}\text { Amount } \\
(000 €)\end{array}$ & Number & $\begin{array}{l}\text { Amount } \\
(000 €)\end{array}$ & Number & $\begin{array}{c}\text { Amount } \\
(000 €)\end{array}$ & & \\
\hline & $\begin{array}{l}\text { R\&D Con- } \\
\text { tracts }\end{array}$ & 384 & $18.176,00$ & 246,7 & $9.933,67$ & 593 & $9.690,00$ & Health and Bio- & Health (Public \\
\hline USC & $\begin{array}{l}\text { Patent Appli- } \\
\text { cations }\end{array}$ & 28.5 & - & 46.6 & - & 41 & - & & Food Industry \\
\hline & $\begin{array}{l}\text { Spin-Off Cre- } \\
\text { ation }\end{array}$ & 2,5 & - & 2 & - & 3.5 & - & $\begin{array}{c}\text { Natural Rces \& } \\
\text { Environment }\end{array}$ & $\begin{array}{l}\text { Fishing and } \\
\text { aquiculture }\end{array}$ \\
\hline
\end{tabular}




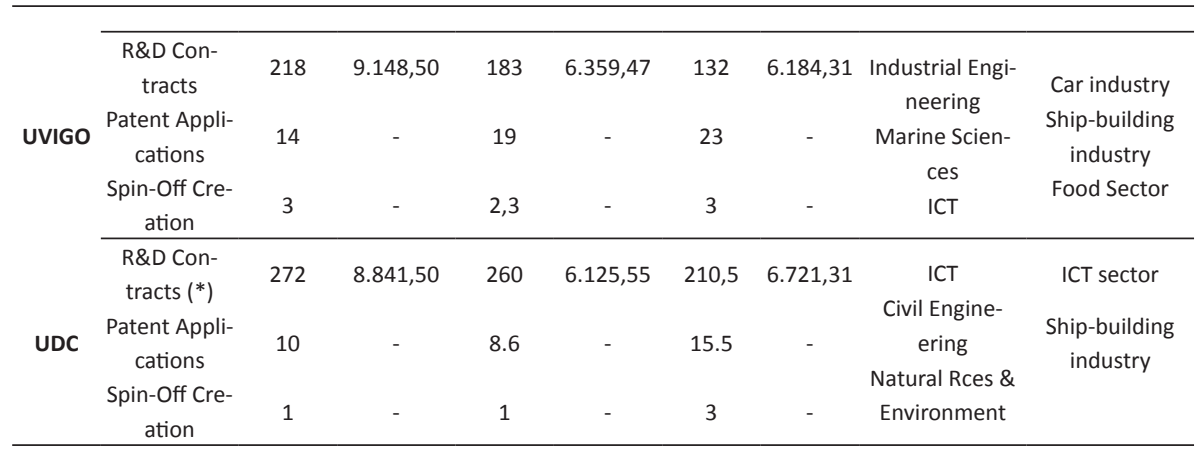

$(*)$ including technical reports.

Source: Own-elaboration based on OTRIS data and interviews.

\section{Strengths and weaknesses of university-industry collaboration in Galicia: a qualitative view}

According to the directors of the TTOs interviewed, the traditional distrust among companies and universities has somehow reduced during the last years, explaining the growing trend of interactions. This has been a progressive process where the beginning of the interaction, sometimes based on small services or consultancy, is seen as a key milestone as it might derivate in more complex collaborations. At the same time, there have been changes in the institutional arrangements (formal and informal) affecting universities views of interactions with industries. These changes refer first of all to the normative and legal developments already mentioned in previous sections but also, according to the TTOs directors views, changes at the behaviour of research and academic personnel are observed. There of course persist barriers referred to the specific culture and norms of academy that, in some cases like the ones related to ideological issues, are hard to overcome. In fact, the debate about the privatization of university (public) knowledge is still a major and open issue when analyzing university-industry interactions. Besides, one of the persons interviewed highlighted the poor value given by the Spanish academy to transfer activities and achievements.

Other weaknesses regard specific legal and normative aspects. One of them refers to the difficulties to make compatible the entrepreneurship activity of researchers with their function in the academy. This is largely due to the specificities of the legal framework affecting labour relationships of public workers. The other factor refers to the inner normative of universities affecting R\&D contracts, patent activity and spin-off creation. The UDC and the UVIGO have just very recently approved the specific normative regulating these aspects whilst the USC still lacks the one referring to patent and spin-off activities. Such lacks do not impede to develop the mentioned 
transfer activities as not-written norms are applied. Nevertheless such "legal vacuum" might act as an obstacle in the future. Finally, the administrative and managerial structure for university industry interactions is another important aspect affecting such interaction. In our case, each university owns a specific structure. At UVIGO, for instance, the TTO do not manage R\&D contracts but only patent and spin-offs activities. At USC it happens the opposite, as the TTO is not in charge of these two last activities that are under the umbrella of other organism. Finally, at UDC -after a long period where the TTO owned very limited functions- they have decided to centralize all activity at this office.

Another important aspect refers to the importance of public funding to support university-industry collaboration, particularly (but not only) from the regional administration. Regional programmes have been important for instance to build service infrastructure supporting spin-offs and entrepreneurship activities at universities. At the same time, general programmes of $R \& D$ and innovation usually encourage collaboration. Nevertheless, according to some of the persons interviewed, the high importance of public support could have had a certain negative effect as it created too much dependence on public funds for the promotion of university-industry collaboration. This would explain the strong reduction of collaborative activities once the crisis burst in 2008. Regarding the relationship with the industrial structure of the region, we have generally observed that its weight on the nature and profile of collaborations is not very relevant. This might be related to the low-tech and traditional profile of most sectors in which the Galician economy is specialized. Nevertheless, a certain structural disconnection between university offer and industrial demand might also exist. Thus, only the food industry, where specific structures like technological centres have been established during last years, shows an increasing but still modest collaborative propensity. In general we can observe that collaboration is too much biased by university scientific and departmental specialization and too little by local and regional industrial specialization. Finally, we asked as well about what university might offer to industry and vice versa. Universities provide a knowledge basis for long term challenges to firms and industries, which are usually more affected by short term problems. Besides, universities are many times a good, highly sophisticated and quite cheap source to solve all kind of technical and production issues. On the other hand, firms might offer to universities a field to test research results as well as an excellent connection to the "real world", i.e. an opportunity to know the problems of the surrounding productive system and an opportunity to adapt less bureaucratic organization structures. 
Table 4. Strengths and weaknesses in the relationships between universityindustryin Galicia

\begin{tabular}{|c|c|}
\hline Strengths & Weaknesses \\
\hline $\begin{array}{l}\text { Existence of a consolidated and general legal } \\
\text { framework that allows university-industry } \\
\text { collaboration }\end{array}$ & $\begin{array}{l}\text { Too much dependence on public funds } \\
\text { for the promotion of university-industry } \\
\text { collaboration }\end{array}$ \\
\hline $\begin{array}{l}\text { Existence of a regional government with } \\
\text { significant competences on innovation } \\
\text { policies that has generally supported } \\
\text { university-industry collaboration }\end{array}$ & $\begin{array}{l}\text { Remaining of some loose ends at legal } \\
\text { frameworks regulating university-industry } \\
\text { collaboration }\end{array}$ \\
\hline $\begin{array}{l}\text { Progressive overcoming of distrusts among } \\
\text { companies and university personnel }\end{array}$ & $\begin{array}{l}\text { Lack of a unique and centralized body at } \\
\text { universities to manage collaborations with } \\
\text { companies }\end{array}$ \\
\hline $\begin{array}{l}\text { Pioneer initiatives at USC like the } \\
\text { establishment of Spin-off incubators and } \\
\text { a venture capital firm }\end{array}$ & $\begin{array}{l}\text { Lack of specific normative regulating } \\
\text { university-industry collaboration (only at the } \\
\text { USC case) }\end{array}$ \\
\hline $\begin{array}{l}\text { Progressive incorporation of some traditional } \\
\text { sectors, with strong presence in the region, to } \\
\text { collaboration dynamics (e.g. food industry) }\end{array}$ & $\begin{array}{l}\text { Collaboration too much biased by university } \\
\text { specialization and too little by regional } \\
\text { industrial specialization }\end{array}$ \\
\hline What University offer to industry & What Industry offers to Universities \\
\hline $\begin{array}{l}\text { Knowledge basis for confronting long term } \\
\text { challenges }\end{array}$ & $\begin{array}{l}\text { A view of the real problems of the productive } \\
\text { system }\end{array}$ \\
\hline \multirow[t]{2}{*}{ High level S\&T solutions at a reasonable cost } & A field for testing research results \\
\hline & $\begin{array}{l}\text { A less bureaucratic organizational structure } \\
\text { (to which adapt) }\end{array}$ \\
\hline
\end{tabular}

Source: Own elaboration.

\section{University-industry collaboration and the institutional framework in Apulia}

The Apulia university system is formed by five universities. The oldest is the University of Bari that was created in 1924 and the University of Lecce, recognized as public university in 1967-68. In the early '90s Polytechnic University was born from a separation of the University of Bari and in 1999 the University of Foggia. Finally, in 1995 the free Apulia Mediterranean University "Jean Monnet" in Casamassima which is not a public University although is legally recognized. Since 1998, in accordance with the Presidential Decree n.25, these five universities have gradually become part of the University Committee for the Coordination of Apulia Region (CURC). Nowadays, the University of Bari is the most significant university, both on size side and in 
terms of number of Faculties and students as well as regarding the number of departments.

About the main research areas, there is some overlapping particularly in the field of social sciences and humanities. Generally, the Uniba shows a strong specialization on health science, chemistry and physics and also on other classical disciplines such as law, economics, philosophy, languages, biology. The Unisalento and Polytechnic mostly focus on mechanics and electronic engineering as well technology; in addition, Unisalento focuses on art sciences and culture; the Unifg is specialized in agricultural sciences and health sciences. Finally, we didn't include LUM (the private university) as it is formed by research staff mostly from other universities. The following scheme shows the hard sciences research areas by universities.

Table 5. Apulia region Universities (2012)

\begin{tabular}{|c|c|c|c|}
\hline & $\begin{array}{l}\text { Students/Sci- } \\
\text { entific Staff }\end{array}$ & Departments & Hard Sciences Research Areas \\
\hline Uniba & $56.305 / 1540$ & 24 & $\begin{array}{l}\text { Biotechnology/Life Science } \\
\text { Chemistry/Physics } \\
\text { New Materials } \\
\text { Computer Science and ICT } \\
\text { Pharmacology } \\
\text { Cultural Heritage } \\
\text { Food and Vegetable Genetics } \\
\text { Health Technologies } \\
\text { Maritime Zoology -Veterinary Medicine }\end{array}$ \\
\hline $\begin{array}{l}\text { Unisalento } \\
\text { (Lecce) }\end{array}$ & $19.426 / 664$ & 8 & $\begin{array}{l}\text { Applied Physics } \\
\text { Cultural Heritage Maintenance } \\
\text { Materials } \\
\text { Hearth Science } \\
\text { Mechatronics } \\
\text { Nanotechnologies }\end{array}$ \\
\hline $\begin{array}{l}\text { Polytechnic of } \\
\text { Bari }\end{array}$ & $12.639 / 299$ & 4 & $\begin{array}{l}\text { Avionics/Aerospace Eng. } \\
\text { Automotive } \\
\text { Mechanics/Mechatronics } \\
\text { Hearth and Water Science } \\
\text { Computer Science and ICT } \\
\text { Transport Engineering }\end{array}$ \\
\hline Unifg & $10.839 / 359$ & 6 & $\begin{array}{l}\text { Agro-Industry } \\
\text { Food Control Techniques } \\
\text { Alternative Energy } \\
\text { Breeding Science and Technology }\end{array}$ \\
\hline
\end{tabular}

Source: Own-elaboration.

For a long time Italian university system was characterized by a low autonomy level because the central government played a significant decisionmaking power in the allocation of financial resources to universities (Baldini, 
2006). According to this trend, the first important financing experience in research field involving universities as well as firms in the framework of extra-ordinary plan for "Mezzogiorno" development permitted to establish in Bari one of the first Italian scientific and technological park (TECNOPOLIS) dated as from the early ' 80 s and arranged by universities, public institutions, companies and banks. However, the first concrete regulatory example on R\&D at national level is represented by law n. 46 of 1982 aimed to introduce new tools for supporting technological development and human resources training in research sector. Before this law, the decree n.382 regarding University Reform of 1980 gave Italian university a wide financial autonomy in order to promote, inter alia, additional research networking and public as well as private funds.

The Decree n. 297 of 1999 authorised universities to issue regulations and lacobucci, lacopini, Micozzi and Orsini (2011) refer that since then let researchers and professors to participate in the capital and management of newly established companies aimed at the industrial use of research ( $p$. 9) and academic staff to be involved in the ownership and management of new initiatives (O'Shea, Chugh and Allen, 2007). These regulatory changes reached good results: Italian universities recorded 17 patents in 1995, 35 in 1997 and 121 in 2001. This act also highlighted the capacity to set up specific offices within the universities like the so called Transfer Technology Offices.

In Italy, the first TTOs were set up just since the 90s, but only between 2001 and 2008 the most of the universities created devoted units, with a boom during the period 2004-2006, because TTOs took advantage of specific government funds. Ultimately, the connected activities to the technology transfer are a fairly recent phenomenon for Italian university and in several cases different structures inside universities (such as patent and research offices) were aggregated into a unique office in order to increase productivity and efficiency. Nowadays, almost all universities and public research institutions have formalized specific TTOs.

Regarding entrepreneurship, although the first regulatory act was the above mentioned Decree, it does not well define the meaning of "spinoff". This decree identifies people eligible for incentives and activities to be specifically considered. The beneficiaries are newly established companies, based on equity participation or, at least, on the commitment of all or some of the university professors and researchers, PhD students, research fellows.

Through the Decree n. 593 of 2004, authorization procedures and intellectual property rights were well defined and each university started to govern the matter autonomously. As we said, thanks to a Decree of 2010 the national government fixed the goal of harmonizing the Italian legal system to European and international standards, but it was ignored so that 
public research lost the likelihood to restore a rule, potentially able to get the ownership of patents by the university and to leave to the researcher the opportunity to be recognized as author and to get royalties. Because of the budget constrain and the growing cuts involved the research funds, universities were encouraged to collaborate with industry.

The Apulia Region planned for the first time an organic programme for technological innovation within the Operational Program of European Regional Policy 1994-99. The connected actions provided technical assistance to SMEs, useful for the development of technological transfer in research sector, high level training for human capital and linkages among existing structures. The goals of regional innovation plan were FAR (Fund of subsiding research) and FIT (Fund for technological innovation) whose general goal was to sustain the R\&D activities, and specific goals to create joint ventures among companies and between those and universities and other research institutions.

Thanks to the new regulations frame by Apulia Region and EU Regional Policy, specific policies for technological innovation were better defined: the Operative Program for 2000-2006 designed infrastructures for scientific and technological innovation and promoted new tools able to create linkages among firms by paying great attention to sectors potentially able to contribute to the research and technological development. Specifically focused on the technology transfer were the Technological Competence Centres, whose main goal is the involvement of SMEs within strategic fields in terms of innovation and technology application (transports, environment, biotechnology, food and ICT). The TCCs were supported by National Operative Programme 20002006 on the base of a call cared by Ministry of University and Research. They involved universities, public and private research organizations as well as firms coming from Nuts II Italian Regions (Apulia, Basilicata, Calabria, Campania, Sardinia and Sicily). These tools contributed to improve the pre-existing situation, even if didn't greatly change the ability of regional system to create and absorb technological innovation. However, the regional strategy carefully preserved both regional industrial policy and a competitive strategy within the international specialization and technology transfer frame, so that in few industrial branches some regional companies became leader in the world.

Although the R\&D supply is mostly based on the university system, other public research centres like National Research Council (CNR), National Body for Alternative Energy (ENEA), National Institute of Nuclear Physics (INFN) and more than forty research labs was recognized by Ministry of University and Research as well as several research consortia like Centre Planning, Design and Technology of Materials (CETMA), National Consortium of Research for Optoelectronic Technologies (OPTEL), Euro-Mediterranean Biomedical 
Scientific Institute (ISBEM) and Laser Centre that, albeit private subjects, have a majority public participation.

The regional law n. 23 of 2007 introduced Technological Districts, that involve companies and local institutions as well as universities and connected research centres in order to develop a common strategic plan. After the establishment of productive cluster in traditional manufacturing (textile, clothing and leather, sofa, etc.), since 2009 the regional R\&I strategy defined a list of economic activities characterized by higher technological contents; then, aero-space, food, cultural heritage, biotechnology and life science, energy and environment, logistics and production technology, mechanics and mechatronics, new materials and nanotechnology, information and communication technology districts started to be implemented and nowadays represent a very interesting productive and technological "network of networks". Then, technological districts are one of the main outcomes arising from the cooperation between central government and regions and a strong tool to empower the regional planning within selected innovative and technological fields and the collaboration among other local institutions, companies, universities and research centres. This mentioned strategy is financially supported by the ERDS, ESF and National Funds.

Even we can meet a regional innovation and research strategy in Apulia region, nevertheless the ongoing reorganization does not seem to have realized long term investments for human resources training; consequently, this affected the innovation path started at the top level of the regional administration system.

\section{The regional production system and specialization of Apulia region}

Apulia is characterized by small and micro firms and only $0.35 \%$ of total has more than 50 employees. Most of these firms are concentrated in low-tech sectors (textile, clothing, footwear, wood and furniture, food) and characterized by networks with subcontractors in several stages of production. Marketing, research and innovation activities are carried out by final firms, often localized outside the region. Several firms are located in some territorial production systems: textile industry in the north of Bari, clothing and footwear in the lower Salento as well as in Itria valley and in the north of Bari; sofa district in Sant'eramo, Gravina and Altamura (all localized on the western border of the region). Opposite, the agri-food system appears to be more widespread albeit with a higher concentration in Bari and Foggia; the steel industry is sited in Taranto, mechanics in Bari, chemicals and pharmaceuticals in Brindisi and Bari, aeronautic and aerospace sector embedded in Brindisi, Foggia and Taranto for the energy sector, aviation and software. In Apulia are located 
global industrial groups such as IBM, Bosch, Edison, ENI, Alenia, Avio, Agusta, FIAT, Aventis, etc.. Own elaborations from Italian Institute of Statistics dataset (ISTAT, 2010) show a more detailed frame in terms of relative specialization index. The figure shows the economic activities with a specialization rate $>$ 1. Results confirm that the most specialized sectors are those included in traditional manufacturing like agriculture, food industry, textile, clothing, wood, which refer a specialization rates $1.5 \leq \mathrm{SI} \leq 3.7$. Then, we have those sectors characterized by a medium specialization level like metallurgy, iron metallurgy, manufacture of motor vehicles, construction, etc.. Although belonging to the tertiary, research and scientific development sector still looks not much specialized showing a specialization rate slightly higher than 0.5 . Finally, no high-tech economic activities show a specialization index higher than 0.5 .

Figure 2. Relative sectoral specialization in Apulia, in relation to Italy (2010)

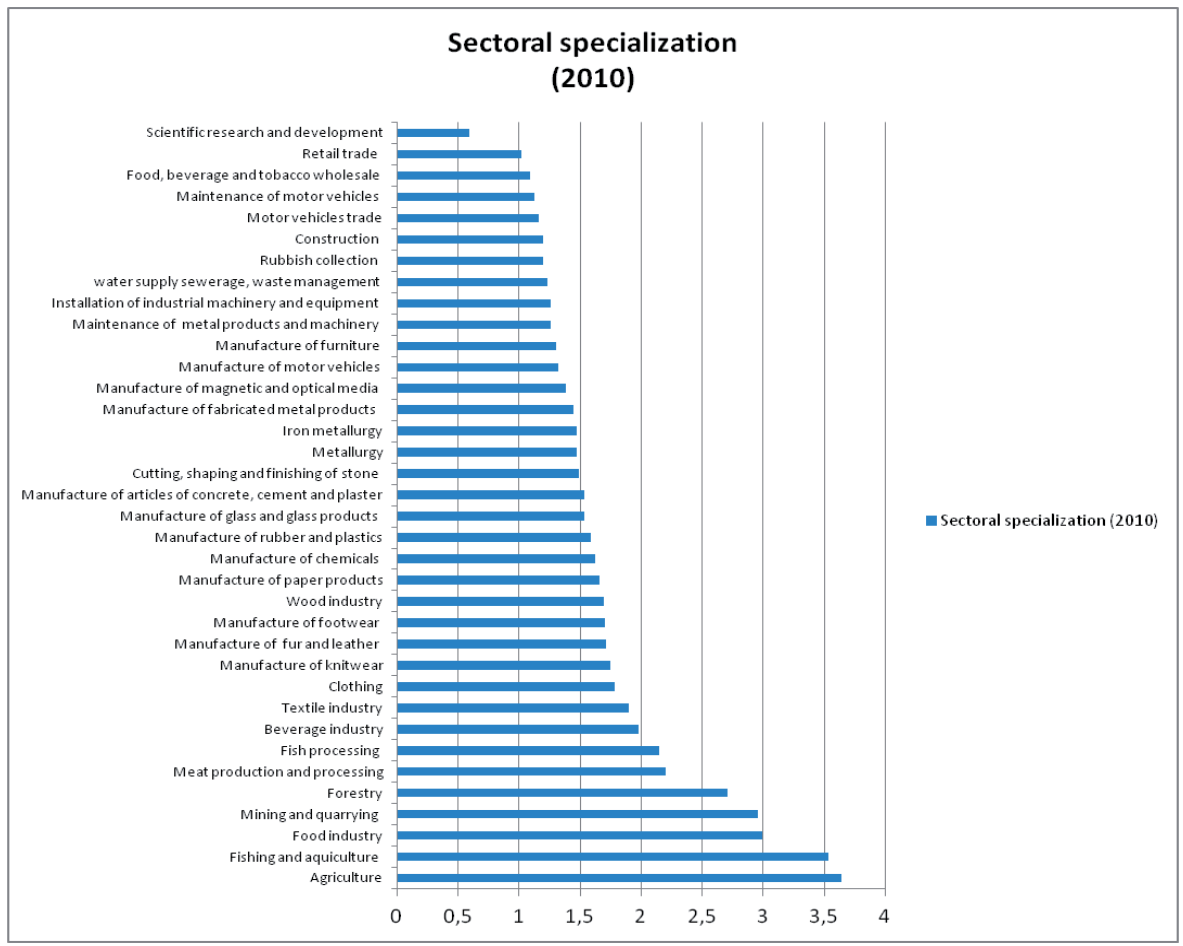

Source: Own elaboration on ISTAT (2010).

When we focus on total investments in scientific research by industry, public and private institutions and universities, the total expenditure is lower than the national and EU average. The gap between regional and national 
expenditure is significant even considering only the R\&D expenditure made by firms. The share of firms expenditure in R\&D on total regional GDP is $0.18 \%$, while in Italy is $0.68 \%$ and in Europe is 1.24 ; overall, although the Italian share in R\&D on GDP in 2010 is rather low (1.26\%), in Apulia is still lower than the national average $(0.71 \%)^{6}$. It means that, despite the presence of selected advanced sectors, Apulia is indeed characterized by low investments in research and innovation. Anyway, both in the starting of leader companies and in the territorial new form of organization of high-tech firms, universities played an important role, being a pillar of knowledge infrastructure system in Apulia too.

Table 6. Main innovation indicators of Apulia and EU-27

\begin{tabular}{lrr}
\hline & \multicolumn{1}{c}{ Apulia } & \multicolumn{1}{c}{ EU-27 } \\
\hline Population (2013) & 4.050 .803 & 501.403 .599 \\
GDPpc (PPS) (2011) & $16.100 €$ & $24.600 €$ \\
Unemployment Rate (2012) & 15,6 & 10,4 \\
R\&D Exp/GDP (2011) & 0,71 & 2,01 \\
Business R\&D Exp/GDP (2011) & 0,18 & 1,24 \\
Patent Applications to EPO per million inh (Average 2006-2010) & 13,38 & 111,56 \\
High-Tech Sectors (\% Total Employment) (2011)* & 6,2 & 10 \\
\hline
\end{tabular}

* High-Tech Manufacturing + High-Tech Knowledge intensive services

Source: Eurostat.

\section{University-industry interaction in Apulia Region: recent evidence}

In the last few years, Apulian universities are making great efforts to promote technology transfer, although operating within an organizational, financial and legal context not so much developed yet and often changing. Focusing on the case of the University of Bari, TTO is currently made up of two structured units staff: an area manager who is also in charge of the Sector i (Spin-offs sector and productive districts) and a vicar in charge of Sector II (Patents protection and intellectual property). Conversely, the TTO of Politechnic of Bari is characterized by a single sector composed by five units staff including the area manager.

The following table shows some relevant outcomes reached by regional universities and institutions as detected by NETVAL annual report. More specifically, our elaborations, related to the most recent survey of 2012 (NETVAL, 2014), compare some remarkable elements between Apulia and Italian case. We use the most recent data related to a single year as it provides less fragmented information and more specific details.

6 Source: Eurostat and Italian Institute of Statistics (ISTAT, 2010). 
Among five regional universities, only four provided data useful to compare them with the national sample. The table displays a lower average value in terms of annual budget compared to the national sample. Anyway, the survey observes a regional value not so low, as it is positioned on the extreme of its range (195,3 Millions euro). In fact, only 14 universities are within the range of $>100-\leq 200$ (Meuro) and 22 within $>200->500$, among 53 answering universities out of 61 belonging to the sample. Data also show very low average values either in terms of doctoral students or contractors ( 384.3 vs $512.7 ; 133.3$ vs 328.1 ). With regards to scientific and technological research funds, regional average value is quite low compared to the correspondent national value (29 million). If we consider the "top 5" universities, which indicate a higher level of research funds (approximately 121 MEuro/university), there is an overall increase compared to 2011.

About inventions, active patents and licensing data show always lower average values compared to the national ones.

Spin offs by public research, although characterized by lower average values compared to the nationals, are growing in absolute terms. More specifically, Tuscany is the region hosting the highest number of spin offs $(10.7 \%)$, followed by Lombardy (10.6\%), Emilia Romagna $(10.2 \%)$ and Piedmont (9.6\%); Apulia recorded 8.3\% (corresponding about to 81 spin offs). Apulia is characterized by a younger profile than other regions as regarding spin offs average life (about 3.4 years). Out of Italian 20 regions, Apulia is at the fourteen place of the ranking even if is the first between the seven regions belonging to the "Mezzogiorno".

Table 7. Some characteristics of universities at regional and national level (2012)

\begin{tabular}{lrrrr}
\hline & Total Apulia & $\begin{array}{c}\text { Average } \\
\text { Apulia }\end{array}$ & Total Italy & $\begin{array}{c}\text { Average } \\
\text { Italy }\end{array}$ \\
\hline $\begin{array}{l}\text { Inizio modulo } \\
\text { Total annual budget of the univ / }\end{array}$ & 781,1 & 195,3 & $12,027,4$ & 226,9 \\
institution (M €)Fine modulo & 1.537 & 384,3 & $27.174,0$ & 512,7 \\
Doctoral students & 533 & 133,3 & $17.063,1$ & 328,1 \\
Contractors & 40,8 & 10,2 & $1.496,4$ & 28,8 \\
Total research funds & 10 & 2,5 & $399(\mathrm{n}=51)$ & 7,8 \\
Inventions & 12 & 3,0 & $201(\mathrm{n}=52)$ & 3,9 \\
Pantents licensing & 116 & 29,0 & $3.356(\mathrm{n}=49)$ & 68,4 \\
Active patents & 10 & 4,0 & & \\
Spin offs (Year 2012) & 81 & 20,25 & & \\
Spin offs (Total number) & & & &
\end{tabular}

Source: Own elaboration based on NETVAL survey (2014). 


\section{Strengths and weaknesses of university-industry collaboration in Apulia: a qualitative view}

Although TTOs are trying to strengthen the promotion of the interdependencies between university and industry, academic members are organized in departments involving broader academic areas that make difficult for industry to identify expertises in the scientific field or for facing with a specific problem. Thus, the role of the technology transfer offices shouldn't differ from the typical function regarding information; in fact, information function by the universities' R\&D services are information professional services. Their main common goal is to lower the entrance barrier for the external business world and to complement existing informal direct contacts between university and industrial world.

Generally, the above mentioned offices have two macro-functions: first, referred to a supporting function for the assessment of projects outcomes, that are aimed at their protection, and economic development implementing patents database and spin offs; this function represents more specifically the technical and operational aspects well known by academic world. Secondly, we refer to an information function dissemination of university's research strengths and the organizations visits to university labs for highlighting university capabilities and facilitating personal contacts between university, industry and society. So, technology transfer office should able to launch special initiatives that lead university closer to industrial world, thanks to effective opportunities of meeting among scientists and industrial workers on specific and common topics of interest. Indeed, many firms still view university as a structure focused on basic research and teaching, unable to develop an attitude in practical matters such as applied research and projects as well.

In addition, these offices should play a role more complex than simple information services: it is sometimes hard to persuade university professors that spreading their expertise is wise and needful; conversely, some academic members suppose that their research experience is enough to play an information role.

Unfortunately, the TTOs are not well-known by university community. Opposite, spreading the TTOs' mission would create a more attractive image both for the office and the university, thanks to the awareness of services that may be provided to the potential customers, included students' placement. So, the TTOs must be able to mediate different and -several times- opposite individual as well as collective expectations.

Among the strengths that characterize university-industry networking in Apulia, firstly we have to highlight the regional knowledge and research infrastructure, that counts on 4 public universities (+ a private one), the local 
office of the main national research institute as mentioned above, and 49 public and private labs acknowledged by Italian Ministry of University and Research, out of the internal labs of the biggest company. Then, Apulia is not at the start-up step of the research-innovation-technology transfer chain (RITECH); rather, it is in a fording position where it is hard to come back as well as to go on, considered that the so called "RITECH" process cannot be tackled trough a "stop and go" strategy.

The second strong point of Apulia ritech system is the involvement of multinational groups (Agusta-Westland, Alenia, Aventis, Avio Aero, Bendix Altekna, Bosh, Edison, Eni, Getrag, Ibm, Ilva, etc.) and, in the same time, of local companies, some of them ranked at the top level in their own branch (Cle, Imp, Insoft, Itel Telecomunicazioni, Mermec, Masmec, Sincon, etc.)

The third condition that can be considered as a strength point is the strategy adopted by regional government in order to support universityindustry collaboration thanks to EU and national funds. As referred above, Apulia Region answered to the most of calls and initiatives promoted at overnational as well as domestic level, acting in the framework of the institutional planning activity (POP 1994-2000; PO 2000-2006; PO 2007-2013), whose outcomes and perspectives are up to dated within the Smart Specialization Strategy 2020 of Apulia Region. This document demonstrates the importance of a governance authority for planning and managing the regional innovation strategy. In Apulia, the regional government is supported by three operative agencies (ARTI, InnovaPuglia, PugliaSviluppo), that complete the panel of the main actors of the industrial policy at Apulia regional level (university, firms, regional government). As industrial policy we mean the body of public activities involving actors, rules and other stakeholders, able to create the conditions for structural economic changes more intensive than the spontaneous transformation that we can get without the same policy (Bianchi and Labory, 2011; Warwick, 2013; Viesti, 2013).

Finally, we can include within the strengths list some other pro-active conditions, such as:

- Young unemployed people having a high education degree (Dileo, Garcia Pereiro, Losurdo, 2013);

- Hi-tech districts of production acting within hi-tech branches;

- Qualified services system;

- Increasing demand for added value services.

Among the weaknesses, first of all we remark a basic point: a lot of barriers against the university-industry cooperation still remain. The most important of these are the long-term orientation of university as well as the lack of suitable government programme in the long term specific research areas. One more weak point is the low profile of TTOs and Regional Industrial 
Liaison Office (ILO), generally due to the lean ability of their staff in managing technology transfer. At least they need a person who is well-known inside the university and has a large personal network of contacts with industry not only at regional but also at international level managing the liaison office. The operational tasks of the TTOs are not optimal for several reasons largely due to the lack of a staff having specific knowledge of the entrepreneurial world as well as devoted research units able to manage the bridging with the industrial sector.

A weakness can be considered the presence of public bodies that should play a role of assistance and technical support to regional governmental authority as well as consulting service to the networks and other operators engaged in the technology transfer. Indeed, sometimes they play a sort of duplication of university-industry networks. We are referring to the role played by some public equivalent bodies, such as InnovaPuglia and PugliaSviluppo that mostly practice a kind of intermediation whose consequence is the crowding out of the devoted organizations like Competence Centres, TTOs, that are the main expression of university-industry cooperation, and the "nodes" of public research centres (i.e. a new form of networking actually in progress thanks to PO-ERDF 2007-2013).

This not necessary duplication adopted by regional agencies contributes to form an additional weakness that is the lean support given by public procurement in order to empower the rithec process and encourage university and industry cooperation to set-up induced projects and promote new firms and goods, new specialization able to integrate the existing ones and to revaluate "traditional" branches of production adopting new materials and process.

Connected to this last weakness is the slow trend of technological upgrading of public bodies, that is a really weak point in terms of technological enhancement of the system and of cooperation university-industry in order to create new firms and additional employment opportunities. Finally, a not organized and well addressed public demand loses the occasion to realize a mix between direct financial subsides and indirect supports, that should be the long term perspective of the integrated system of networking, that Apulia regional government is trying to create by joining research organizations and firms.

Universities would offer to entrepreneurial world their research ability cumulated over time, continuity in accessing to consultants and patent rights, new business opportunities as well new highly skilled graduates potentially able to create new ideas and improving the performance of firms. In addition, the industrial world might offer to universities a more practical approach and technical methods as well as enriching teaching programs through devoted 
stages useful for job placement and implementing new model of decision making.

Finally, although the utility is not clearly perceived, especially in the short term, the impact of a triple connection TTO-University-Firm would stimulate the productivity through the mutual and stable interaction between different agents involved in this process. In this case, the interest of researchers and professors in the collaboration between university and industry is potentially higher. In fact, the simultaneous connection between the marketing capabilities of TTOs, scientific competence of the academic staff as well as the entrepreneurial vision would provide faster updates on the development dynamics both at local and regional level. The outcomes arising by this relation could be converted into higher publications level, more participation in international conferences and international scientific agreements.

Table 8. Strengths and weaknesses in the relationships between universityindustry in Apulia region

\begin{tabular}{|c|c|}
\hline Strengths & Weaknesses \\
\hline $\begin{array}{l}\text { Presence of a wide regional knowledge } \\
\text { infrastructure }\end{array}$ & $\begin{array}{l}\text { High polarization among traditional industry } \\
\text { and hi-tech branches }\end{array}$ \\
\hline $\begin{array}{l}\text { Availability of a regional strategy for scientific } \\
\text { research }\end{array}$ & $\begin{array}{l}\text { Low propensity to } R \& D \text { investment } \\
\text { expenditure }\end{array}$ \\
\hline $\begin{array}{l}\text { Reference multinational groups and SMEs } \\
\text { leader players }\end{array}$ & $\begin{array}{l}\text { Lean demand for innovation and modest role } \\
\text { of public procurement }\end{array}$ \\
\hline Increasing demand for added value services & $\begin{array}{l}\text { Duplication of roles and functions within tech } \\
\text { transferring system }\end{array}$ \\
\hline $\begin{array}{l}\text { Districts of production acting within hi-tech } \\
\text { branches }\end{array}$ & $\begin{array}{l}\text { Moderate rate of young people with medium- } \\
\text { high level education }\end{array}$ \\
\hline $\begin{array}{l}\text { Young unemployed people having a high } \\
\text { education degree }\end{array}$ & $\begin{array}{l}\text { Low profile of public agents working in } \\
\text { research field }\end{array}$ \\
\hline What University offer to industry & What Industry offers to Universities \\
\hline Own research capacity & $\begin{array}{l}\text { Access engineering, technical development, } \\
\text { manufacturing }\end{array}$ \\
\hline $\begin{array}{l}\text { Continuity in accessing to consultants and } \\
\text { patent rights }\end{array}$ & $\begin{array}{l}\text { Enriching teaching programs through devoted } \\
\text { stages }\end{array}$ \\
\hline New ideas and business opportunities & Placement and job opportunities \\
\hline Recruitment of graduates & New model of decision making \\
\hline
\end{tabular}

Source: Own elaboration.

\section{Conclusion}

In general terms we can affirm that a progressive transition from a mode1 to a mode- 2 system has occurred at the relational framework affecting universities and industry both in Apulia and Galicia. This has affected both 
the formal (legal) and informal (behaviours) frameworks. Thus, we have seen that although normative and legal changes have first occurred in Galicia and as a consequence universities own TTOs since early 90s, in Apulia these changes have also happened some years later. Moreover, TTOs are organized -generally speaking- in a very similar way at both regions, performing very similar functions.

In both regions, public support -particularly from the regional levelhas been a key instrument to promote the interaction of university-industry collaboration. Different programmes, like the one supporting technologicalproductive districts in Apulia or the R\&D plans in Galicia, have encouraged the joint participation in R\&D projects of business and universities research bodies. The effort of Apulia decision maker to create a critical mass of research-innovation-technology system is producing appreciable outcomes in terms of changes affecting university-industry relationship. Public support could nevertheless have created certain dependence on public funds dependence as shown in the Galician case with the strong reduction of R\&D contracts between universities and industry due to the cut of public funds in the crisis period.

Moreover, in both cases certain barriers coming from the different cultures and institutional behaviours remain. Long term university views contrast with short-term and concrete needs of industry. This might be related to a still short tradition in cooperation since, as noted in the Galician case, beginning a collaborative experience even when the R\&D content is low, makes a difference for the future development. In any case a certain culture that gives little value to transfer activities at universities -in Spain- or visions centred on sectoral instead of interdependent approaches -in Italy(Losurdo and Dileo, 2014), are still performing as obstacles. Time is needed to consolidate cultural and behavioural changes at both university and industries.

Other barriers refer to normative aspects which still remain uncertain, like the possibility to make compatible entrepreneurship and academic activities in Galicia, or the legal framework affecting patent and authorship in Italy.

Regarding the productive specialization, from the Italian case we have learnt that the low propensity of industry to invest in R\&D and innovation activities, is a major barrier for collaboration with universities. This is particularly relevant when dealing with traditional industry and the Apulia case shows strong differences between this industry and hi-tech branches, when dealing with collaboration activities. This evidence reinforces the results found by Isaksen and Karlsen (2010) for the Norwegian case, where STI dominated industries were more prone to cooperate with universities than 
DUI industries. In relation with this, in the Galician case we have observed that collaboration is somehow too much biased by the university scientific and departmental specialization and too little by industrial specialization. This might be related to the low-tech profile of regional industry but probably an adjustment of the university offer in terms of research and academy is also needed. Actually, some traditional activities, like the food industry in the Galician case, have progressively been involved in collaboration action with universities.

Further research on university-industry collaboration, based on the Apulia region and Galicia case, will try to observe how this interaction enters into and shapes the innovation system of each region. At the same time, although a large-scale research will be needed, it will be very interesting to analyze in depth the impact of university-industry collaboration in the development of these two less-favoured European regions.

Finally, according to other experiences, it will be interesting to test in Galicia and Apulia the effect of firm's size into the likelihood of intensifying the cooperation with university as well as whether or not the presence of employees with higher university degree may improve the absorptive capacity of enterprises. It will be also interesting to investigate whether the difference between STI and DUI industry modes of innovation stand in our case or not to explain collaboration between university and industry.

\section{References}

Acs, Z.J., Audretsch, D.B. (2003). Handbook of Entrepreneurship Research. The Netherlands: Kluwer Academic Publishers.

Alavi, M., Leidner, D. (2001). Knowledge management and knowledge management system: conceptual foundations and research issues. MIS Quarterly, 25(1), 107-136.

Aydalot, P. (1986). Milieux Innovateurs en Europe. Paris: GREMI.

Baldini, N. (2006). University patenting and licensing activity: a review of the literature. Research Evaluation, 15(3), 197-207.

Basant, R. (2002). Knowledge Flows and Industrial Clusters: an Analytical Review of Literature. Economic Study Area, Working Papers, 40, EastWest Center.

Bathelt, H., Malmberg, A., Maskell, P. (2004). Clusters and knowledge: local buzz, global pipelines and the process of knowledge creation. Progress in Human Geography, 28(1), 31-56.

Bianchi, P., Labory, S. (2011). Economic crisis and industrial policy in the Union: the need for a long-term vision of industrial development. In: P. Della Posta, L.S. Talani (Ed.), Europe and Financial Crisis (pp.107-124). Basingstoke: Palgrave Macmillan. 
Boucher, G. Conway, C. Van Der Meer, E. (2003). Tiers of engagement by universities in their region's development. Regional Studies, 37(9), 887897.

Camagni, R., Maillat, D., Matteaccioli, A. (2004). Ressources Naturelles et Culturelles, Milieux et Développement Local. Neuchâtel: EDES.

Carayannis, E.G., Campbell, D.F. (2011). Open innovation diplomacy and a 21st century fractal research, education and innovation (FREIE) ecosystem: building on the quadruple and quintuple helix innovation concepts and the "mode 3" knowledge production system. Journal of the Knowledge Economy, 2(3), 327-372.

Carlsson, B. (1997). Technological Systems and Industrial Dynamics. Boston, MA: Kluwer Academic Publishers.

Carlsson, B., Jacobsson, S., Holmèn, M., Richne, A. (2002). Innovation system: analytical and methodological issue. Research Policy, 31(2), 233-245.

Castells, M., Hall, P. (1994). Technopoles of the World. London: Routledge.

Conde-Pumpido, R. (2007). As relacións Universidade-empresa na conformación do sistema de innovación galego: contexto histórico da transferencia de tecnoloxía en Galicia. Grial: Revista Galega de Cultura, $175,72-85$.

Dileo, I., Garcìa Pereiro, T., Losurdo, F. (2013). Analysing employability determinants of the italian labour market: the case of italian graduates. Economia dei Servizi, 8(2), 127-145.

Etzkowitz, H., Leydesdorff, L. (2000). The dynamics of innovation: from national systems and "mode 2 " to a triple helix of university-industrygovernment relations. Research policy, 29(2), 109-123.

European Commission, (2014). Regional Innovation Scoreboard.

Fini, R., Grimaldi, R., Santoni, S., Sobrero, M. (2011). Complements or substitutes? The role of universities and local context in supporting the creation of academic spin-offs. Research Policy, 40(8), 1113-1127.

Gibbons, M., Limoges, C., Nowotny, H., Schwartzman, S., Scott, P., Trow, M. (1994). The New Production of Knowledge: the Dynamics of Science and Research in Contemporary Societies. London: SAGE.

González-López, M. (2000). a colaboración entre universidade e industria no marco dos sistemas rexionais de innovación: o caso galego. Revista Galega de Economía, 9(2), 43-66.

González-López, M. (2009). Regional differences in the growth patterns of knowledge-intensive business services: an approach based on the spanish case. European Urban and Regional Studies, 16(1), 101-106.

Gunasekara, C. (2006). Reframing the role of universities in the development of regional innovation systems. The Journal of Technology Transfer, 31(1), 101-113.

Howels, J. (1999). Regional systems of innovation? In: D. Archibugi, J. Howells, J. Michie (Ed.), Innovation Policy in a Global Economy (67-93). Cambridge: Cambridge University Press. 
lacobucci, D., lacopini, A., Micozzi, A., Orsini, S. (2011). Fostering entrepreneurship in academic spin-offs. International Journal of Entrepreneurship and Small Business, 12(4), 513-533.

Isaksen, A., Karlsen, J. (2010). Different modes of innovation and the challenge of connecting universities and industry: case studies of two regional industries in Norway. European Planning Studies, 18(12), 1993-2008.

Losurdo, F., Dileo, I. (2014). Rural-industrial policy as a multi-outcome path in the post crisis era. International Journal of Public Policy, 10(6), 279-295.

Lundvall, B.A. (2006). One Knowledge Base or Many Knowledge Pools? Danish Research Unit for Industrial Dynamics. DRUID Working Paper, Alborg.

NETVAL (2014). Survey on the Valorization of University Research.

O'Shea, R., Chugh, H., Allen, T. (2007). Determinants and consequences of universities spin-off activity: a conceptual framework. Journal of Technology Transfer, 33(6), 653-666.

Rubiralta, M. (2007). La transferencia de la I+D en España, principal reto para la innovación. Economía Industrial, 366, 27-41.

Uybarra, E. (2010). Conceptualizing the regional roles of universities, implications and contradictions. European Planning Studies, 19(8), 12271246.

Vence-Deza, X. (1992). o sistema de ciencia-tecnoloxía e as asimetrías nas relacións universidade-industria. Revista Galega de Economía, 1(1), 2548.

Vence-Deza, X., González-López, M. (2008). Regional concentration of the knowledge-based economy in the EU: towards a renewed oligocentric model?. European Planning Studies, 16(4), 557-578.

Viesti, G. (2013, 12 February). Una Nuova Politica Industriale per l'Italia [post]. Retrived from http://www.italianieuropei.it/italianieuropei-2-2013/ item/2957-una-nuova-politica-industriale-per-litalia.html.

Warwick, K. (2013). Beyond Industrial Policy: Emerging Issues and New Trends. Technology and Industry Policy Papers, 2, 1-57. doi: 10.1787/5k4869clw0xp-en.

\section{Abstrakt (in Polish)}

Uniwersytety pełniq rolę jednego z kluczowych podmiotów w ramach narodowych i regionalnych systemów innowacji. Charakter współpracy między uniwersytetami i przedsiębiorstwami zmienit się ciqgu ostatnich kilkudziesięciu lat, przy czy wykazuje on znacznq różnorodność w poszczególnych krajach i regionach. Interakcję między tymi podmiotami determinuje szereg czynników, poczquwszy od branżowej struktury terytorium, aż po uwarunkowania instytucjonalne i prawne. Celem artykułu jest poszerzenie rozumienia tego procesu, na podstawie porównania dwóch europejskich regionów (nuts-2) - włoskiej Apulii i hiszpańskiej Galicji. Rezultaty badań wskazujq, że w obu regionach nastapił rozwój od rozproszonego do zintegrowanego podejścia $w$ relacjach między naukq i gospodarkq. Istotna rolę $w$ rozwoju współpracy między 
środowiskiem naukowym i przedsiębiorstwami w Galicji i Apulii odegrała polityka gospodarcza, szczególnie na poziomie regionalnym.

Jednocześnie jednak ciqgle występujq kulturowe i instytucjonalne bariery, zarówno po stronie środowiska akademickiego, jak i biznesowego, które utrudniaja właściwe ukierunkowanie i większq efektywność współpracy. Ograniczeniem jest z jednej strony niski poziom kultury innowacyjnej obserwowany w tradycyjnych branżach, które dominujq w obu regionach. z drugiej zaś strony, istnieje także potrzeba lepszego dostosowania badań prowadzonych przez uniwersytety, gdyż sq one bardziej uzależnione od naukowej i funkcjonalnej specjalizacji uczelni niż lokalnej i regionalnej specjalizacji przemysłu.

Słowa klucze: uniwersytet, gospodarka regionalna, współpraca, regiony.

\section{Biographical Notes}

Manuel González López is a PhD lecturer and researcher at the Department of Applied Economics in the University of Santiago de Compostela, Galicia (Spain). He holds a MSc and MPhil in Social Sciences from the University of Manchester (UK) and he has been a visiting researcher at several European universities. His main fields of research are Economics of Innovation, Regional Economics in the European Union and more recently also the industrial and innovation dynamics of the Food Sector. He has published numerous papers in different journals like European Urban and Regional Studis, Environment and Planning $\mathrm{C}$ or European Planning Studies. He has also particiapated in several European research projects

Francesco Losurdo is a Professor of Economics at the Department of Political Science, University of Bari (IT), General Secretary of Community of Mediterranean Universities, President of Daisy-net Competence Centre. He was Visiting Professor at the Universidad Argentina de la Impresa, Universidad de Conceptiòn del Uruguay. He also was Visiting Professor at the University of Szczecin (PL), University of Warmia and Masuria at Olsztyn (PL) and University of Hankuk at Seoul. His research interests have focused on industrial policy, regional policy and planning and assessment of European programmes.

Ivano Dileo received his $\mathrm{PhD}$ in Demography and Economics at the University of Bari 'Aldo Moro' focusing on industrial agglomeration of economic activities. He was a visiting PhD student at the University of Sheffield (UK) and Visiting Researcher at the University of Santiago de Compostela (SP). His research interests have mostly focused on industry, innovation and regional development. 
